
on dc link, pp. 558 - 576

\title{
VOLTAGE AND CURRENT HARMONIC SUPPRESSION BY SHUNT ACTIVE FILTER FEEDING DC LOAD ON DC LINK
}

\author{
Gaber El-Saady ${ }^{1}$, Ashraf Hemeida ${ }^{2}$, and M. Nasrallah ${ }^{3, *}$ \\ ${ }^{1}$ Power Engineering and Machines Department, Faculty of Engineering, Assiut University, Asyut, \\ Egypt,E-mail address: gaber_1@yahoo.com \\ ${ }^{2}$ Electrical Engineering Department, High Institute of Energy, South Valley University, Aswan, \\ Egypt, E-mail address: ahemeida@yahoo.com \\ 3,* Power Engineering and Machines Dep., Faculty of Eng, South Valley University, Qena, Egypt
}

Received 29 September 2012; accepted 17 November 2012

\begin{abstract}
Shunt active filter is used for suppression of current harmonics of nonlinear load to adjust total harmonics distortion (THD) of terminal voltage to the IEEE standards to improve the power quality. A specific control strategy which uses voltage detection of harmonic to reduce harmonics distortion in the waveforms of source current and terminal voltage resulting from distorted source and nonlinear load (together or separately) is applied. Moreover, the proposed control strategy is used to adjust the terminal voltage without effect on the other loads connected to the same common coupling point. This is used to reduce the voltage drop caused by current source by reducing harmonics on distribution power system to improve the power quality. The effectiveness and reliability of the specific control strategy used to control the shunt active filter has been verified by simulation results. In addition, theoretical analysis is presented to confirm the validity of the simulation results.
\end{abstract}

Index Terms-Active filter, power quality, harmonic suppression in distribution power system.

\section{Introduction}

Over the past few years, the growth in the use of nonlinear loads has caused many power quality problems like high current harmonics, low power factor and excessive neutral current. Nonlinear loads appear to be current sources injecting harmonic currents into the supply network through the utility's point of common coupling(PCC). This results in distorted voltage drop across the source impedance, which causes voltage distortion at the PCC. Other customers at the same PCC will receive distorted supply voltage, which may cause overheating of power factor correction capacitors, motors, transformers and cables, and mal-operation of some protection devices. Therefore, it is important to install compensating devices to eliminate the harmonic currents produced by the nonlinear loads.

So far, shunt passive filters have hitherto been used to suppress harmonics in power systems. However, shunt passive filters have many problems to discourage their applications[1]. Some publications have described the necessary limits for THD like [2], which mention the IEEE Std 519-1992 harmonic limits.

\footnotetext{
* Corresponding author.

E-mail address: nasrallah_1@yahoo.com
} 
G. El-Saady et al, voltage and current harmonic suppression by shunt active filter feeding dc load on dc link, pp. 558 - 576

In recent years there has been considerable interest in the development and applications of active filters because of the increasing concern over power quality [1]. In the past, there has been a number of surveys on various aspects of this topic. Several publications [3-5] have described review of active filters for power quality improvement and technological review. Quantitative analysis of shunt active filter compensation characteristics under different rectifier load situations is described in [6]. Comparisons in circuit configuration and filtering performance between hybrid and pure shunt active filters is described in [7]. In [8], design and implementation of a DSP-based shunt active power filter in three phase four wire system is presented. In [9], design of single-phase shunt active filter for threephase four-wire distribution systems is discussed. Other several publications [10-20] have described different techniques in steps of control strategy used to control the operation of active filters because the control strategy is the heart of the active filter as mention in [3]. For the distorted node voltage, the current waveform is artificially distorted for the harmonic suppression of both the node voltage and the source current and this discussed in [21-22]. Reference [23] presents the current waveform of the pulse width modulated (PWM) converter system for suppressing the harmonics of the terminal voltage and the source current. The authors propose the current waveform whose harmonic components are in phase with the terminal voltage harmonics, by which damping of the harmonic propagation over the distribution system is possible.

This proposed paper uses control strategy of reference [23] to control the operation of shunt active filter for suppression of large amount of THD of current source and terminal voltage to the limit of IEEE standard mentioned above. Also operation of this control strategy with DC load on Dc link is studied. The effectiveness and riability of the specific control strategy used with shunt active filter has been verified by simulation results. In addition, theoretical analysis is presented to confirm the validity of the simulation results.

\section{Shunt active filter based on voltage detection control strategy}

\subsection{System configuration}

Figure. 1 shows a simple model of a power distribution system. The voltage source $V_{s}$ is a distorted three-phase voltage. $R_{s}, L_{s}$, and $C$ are line resistance, inductance, and power factor correction PFC capacitor, respectively.

\subsection{Shunt active filter}

Figure. 2 shows a power circuit of the active filter used: It consists of a three-phase voltage-fed PWM inverter using six IGBTs, three interfacing inductors $\mathrm{L}_{\mathrm{a}}$ and a dc capacitor $\mathrm{C}_{\mathrm{dc}}$. The active filter connected in parallel to the end bus of the line is controlled in such a way as to draw the compensating current $\mathrm{i}_{\mathrm{C}}$ from the line.

Journal of Engineering Sciences, Assiut University, Faculty of Engineering, Vol. 41, No. 2, March, 2013,E-mail address:jes@aun.edu.eg 
G. El-Saady et al, voltage and current harmonic suppression by shunt active filter feeding dc load on dc link, pp. 558 - 576

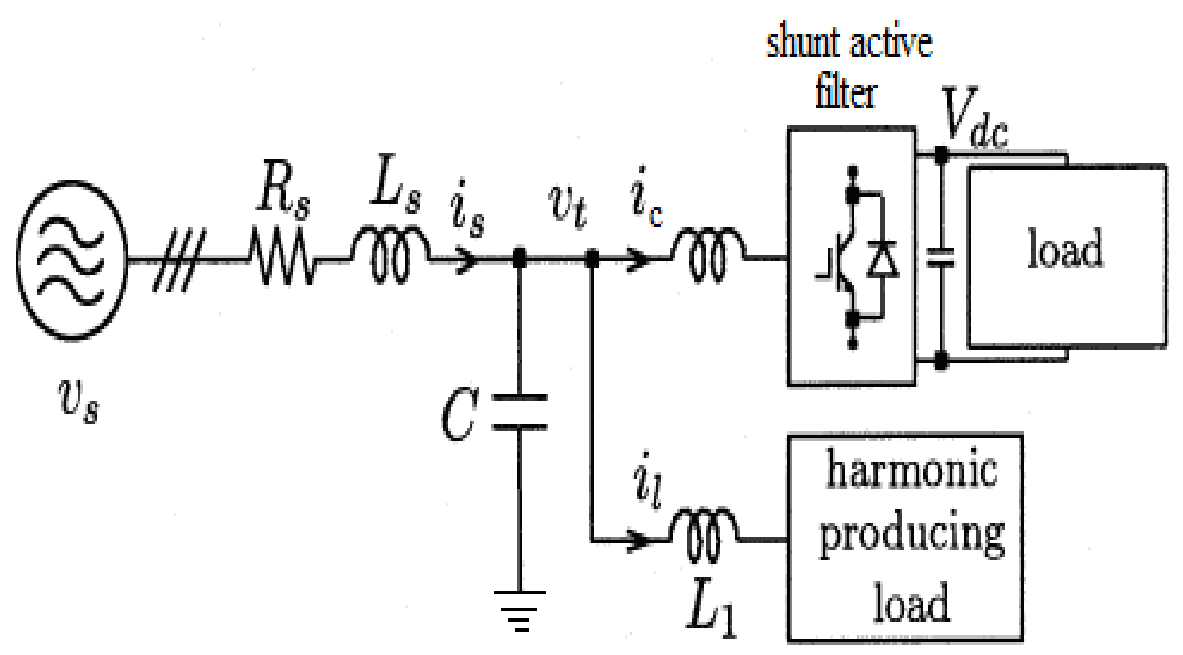

Fig. 1. Model of power distribution system

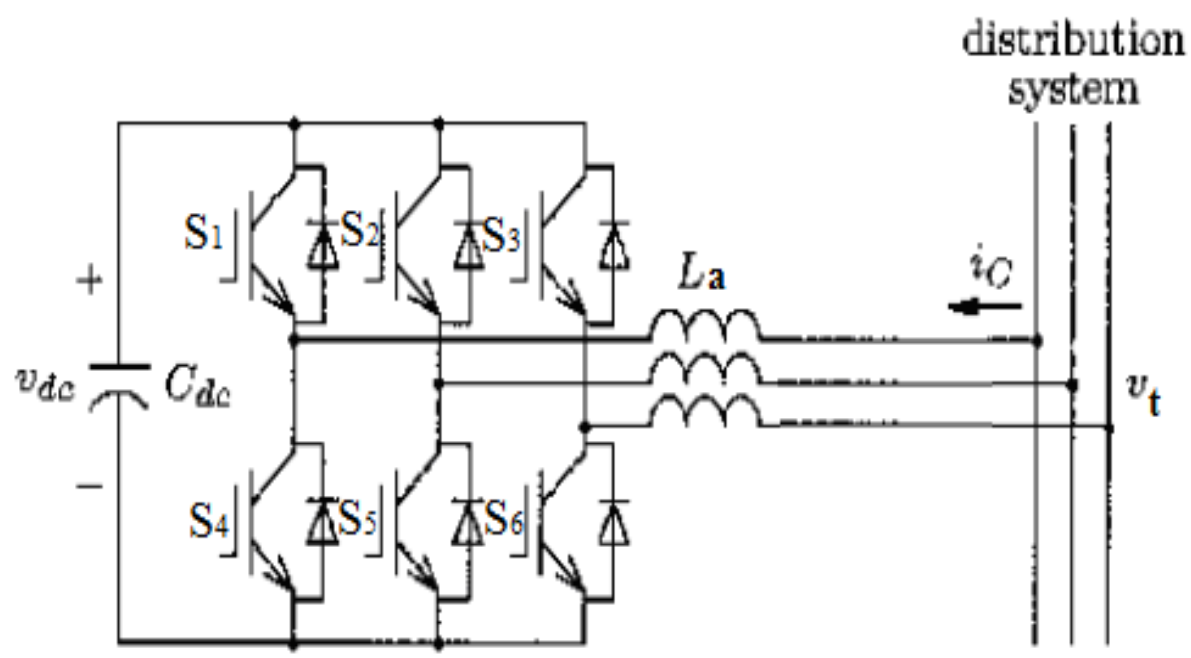

Fig. 2. Power circuit of the shunt active filter

Journal of Engineering Sciences, Assiut University, Faculty of Engineering, Vol. 41, No. 2, March, 2013,E-mail address: jes@aun.edu.eg 
G. El-Saady et al, voltage and current harmonic suppression by shunt active filter feeding dc load on dc link, pp. 558 - 576

\subsection{Control strategy of the shunt active filter}

Generally, the terminal voltage $V_{t}$ of the common coupling point is distorted, due to the existence of the voltage harmonics of the voltage source $V_{s}$ and the current harmonics of the load harmonic, and is given in (1).

$$
v_{t}(t)=v_{t f}(t)+v_{t h}(t)
$$

Where $V_{t f}(t)$ and $V_{t h}(t)$ are the fundamental and harmonic components of the terminal voltage $V_{t}$, respectively.

Under the assumption that the actual compensating current $i_{c}$ is equal to its reference $i_{c}^{*}$, the active filter behaves like an impedance of $1 /|\mathrm{G}| \mathrm{k}[\Omega]$ for harmonic frequencies, taking into account the polarity of $i_{c}$ in FIGURE 2. Hence the active filter acts as a damping resistor or a harmonic terminator to mitigate harmonic resonance in the distribution line.

In voltage detection each phase voltage $V$ is detected at the point of installation, and then is separated to fundamental component and harmonic components by controlling as described later on. finally, the controller produces a compensating current references $i_{c}{ }_{c}$ based on the behaves of active filter like a resistor and voltage detection method. therefore, $i_{c}^{*}$ is given in (2).

$$
\begin{aligned}
i_{\mathbf{c}}^{*}(t) & =i_{\mathbf{c} f}(t)+i_{\mathbf{c h}}(t)=G v_{t f}(t)+|G| K v_{t h}(t) \\
i_{\mathbf{c} f}(t) & =G v_{t f}(t), i_{\mathbf{c} h}(t)=|G| K v_{t h}(t),
\end{aligned}
$$

Where $\mathrm{G}$ is a variable by which the current amplitude should be determined and $\mathrm{K}$ is a constant which determines the amplitude of the current harmonics. According to reference [23] G must be lower than zero for the PWM to work as inverter and active filter work only as inverter .

FIGURE 3 shows a block diagram of the control strategy to detect the voltage to control the dc voltage and to generate the gate pulses. Three-phase voltages at the point of installation, $V_{t a}, V_{t b}$ and $V_{t c}$, which are detected by potential transformers (PT), are transformed to $V_{t p}$ and $V_{t q}$ on the d-q coordinates which is synchronously rotating with the source or line phase angle wt, according to equation (3).

$$
\begin{aligned}
{\left[\begin{array}{l}
v_{d} \\
v_{q}
\end{array}\right]=\sqrt{\frac{2}{3}}\left[\begin{array}{cc}
\cos \omega t & \sin \omega t \\
-\sin \omega t & \cos \omega t
\end{array}\right] } \\
\cdot\left[\begin{array}{ccc}
1 & -1 / 2 & -1 / 2 \\
0 & \sqrt{3} / 2 & -\sqrt{3} / 2
\end{array}\right]\left[\begin{array}{c}
v_{a} \\
v_{b} \\
v_{c}
\end{array}\right]
\end{aligned}
$$

Journal of Engineering Sciences, Assiut University, Faculty of Engineering, Vol. 41, No. 2, March, 2013,E-mail address: jes@aun.edu.eg 
G. El-Saady et al, voltage and current harmonic suppression by shunt active filter feeding dc load on dc link, pp. 558 - 576

Now to divide the components of $V_{t}$ in $d-q$ axis $V_{t p}$ and $V_{t q}$ into the fundamental components $V_{t p f}$ and $V_{t q f}$ and the harmonic ones $V_{t p h}$ and $V_{t q h}$ the low-pass filters (LPFs) and the high-pass filters (HPFs) with a cut off frequency of $6 \mathrm{~Hz}$ are used as shown in FIGURE 3. Then the compensation current of the proposed filter current references $i_{c p}{ }_{c p}$ and $i_{c q}{ }_{c q}$ on the $d-q$ coordinates are obtained by the following equation depending on equation (2).

$$
\begin{aligned}
& i_{\mathrm{c} p}^{*}=G v_{t p f}+|G| K v_{t p h} \\
& i_{\mathrm{c} q}^{*}=G v_{t q f}+|G| K v_{t q h}
\end{aligned}
$$

The variable $\mathrm{G}$ is determined by the proportional-integral $(\mathrm{PI})$ regulator for the $\mathrm{dc}$ voltage difference between the reference $V_{d c}^{*}$ of $350 \mathrm{~V}$ and the detected voltage $V_{d c}$.

Finally, $i_{c p}{ }_{c p}$ and $i_{c q}^{*}$ are transformed into three-phase compensating current references $i_{c a}^{*}$, $i_{c b}^{*}$ and $i_{c c}^{*}$ for the active filter using equation (5) as follows:

Once the active power filter APF reference compensation currents are determined, the current are used as input to the hysteresis current controller to produce switching signals for the PWM inverter. Using the hysteresis-band PWM technique allows the output signal to oscillate within a predefined error band with advantages of quick response and no need of information of the inverter load characteristics. The dc voltage can be controlled via a small amount of active power fed by the source to cover the inverter switching loss. All control strategy is found in DSP of the experimental system of digital controlled shunt active filter.

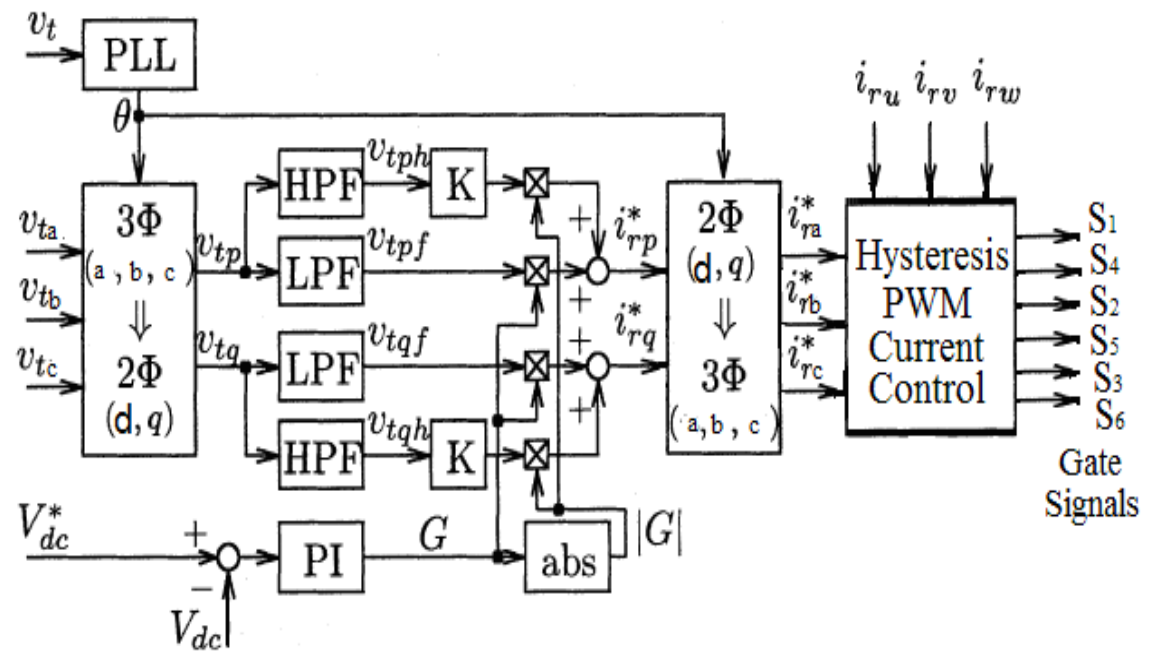

Fig. 3. Control strategy of shunt active filter

Journal of Engineering Sciences, Assiut University, Faculty of Engineering, Vol. 41, No. 2, March, 2013,E-mail address:jes@aun.edu.eg 
G. El-Saady et al, voltage and current harmonic suppression by shunt active filter feeding dc load on dc link, pp. 558 - 576

\section{Harmonic suppression effect of the system with shunt active filter}

Figure. 4 shows the single-phase equivalent circuit for harmonics of the distribution model in FIGURE 1 . In the figure, the voltage source $v_{s h}$ and the current source $i_{l h}$ represent the harmonic voltage of the distorted voltage source $V_{s}$ and the harmonic current of the harmonic producing load, respectively. The source harmonic current $i_{s h}$, the terminal harmonic voltage $v_{t h}$, the capacitor harmonic current $i_{F h}$, and he harmonic current $i_{c h}$ of the shunt active filter in FIGURE 4 are given by:

$$
\begin{aligned}
& i_{s h}=i_{\mathrm{Fh}}+i_{c h}-i_{l h} \\
& v_{t h}=v_{s h}-\frac{i_{s h}}{Y_{s}} \\
& i_{F h}=Y_{c} v_{t h} \\
& i_{c h}=|G| K v_{t h}
\end{aligned}
$$

Where the line admittance $\mathrm{Y}_{\mathrm{s}}$ and the capacitor admittance $\mathrm{Y}_{\mathrm{c}}$ are given by:

$$
\begin{aligned}
& Y_{s}=1 /\left(R_{s}+j \omega L_{s}\right) \\
& Y_{c}=j \omega C
\end{aligned}
$$

using the above relations from (5) to (10), $v_{t h}$ and $i_{s h}$ are given as follows:

$$
\begin{aligned}
& v_{t h}=\frac{1}{Y_{s}+Y_{c}+|G| K} i_{l h}+\frac{Y_{s}}{Y_{s}+Y_{c}+|G| K} v_{s h} \\
& i_{s h}=-\frac{Y_{s}}{Y_{s}+Y_{c}+|G| K} i_{l h}+\frac{Y_{s}\left(Y_{c}+|G| K\right)}{Y_{s}+Y_{c}+|G| K} v_{s h}
\end{aligned}
$$

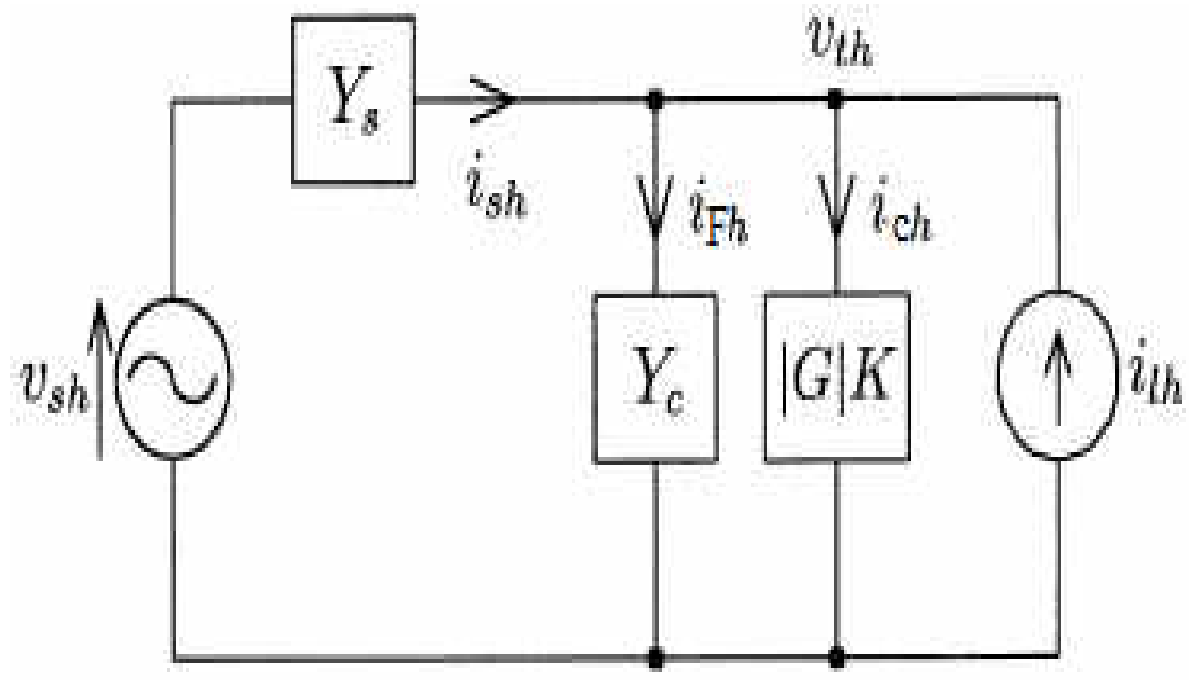

Fig. 4. Equivalent circuit for harmonics of distribution system

Journal of Engineering Sciences, Assiut University, Faculty of Engineering, Vol. 41, No. 2, March, 2013,E-mail address: jes@aun.edu.eg 
G. El-Saady et al, voltage and current harmonic suppression by shunt active filter feeding dc load on dc link, pp. 558 - 576

There are three cases for the harmonic sources, which can be summarized as follows:

\subsection{Harmonic current source}

Under constant harmonic current source $i_{l h}$ and $v_{s h}=0$, the terminal harmonic voltage $v_{t h}$ and the source harmonic current $i_{s h}$ are given as follows:

$$
\begin{aligned}
& v_{t h}=\frac{1}{Y_{s}+Y_{c}+|G| K} i_{l h} \\
& i_{s h}=-\frac{Y_{s}}{Y_{s}+Y_{c}+|G| K} i_{l h}
\end{aligned}
$$

It's clear from the above two equations (13) and (14), that the harmonic suppression effect on the terminal voltage $v_{t h}$ and the source current $i_{s h}$ is decided by the control in the admittance IGlk ,because it is the only admittance available for change or control. For higher harmonic suppression effect is obtained by changing the constant $\mathrm{k}$ in direction that increase the denominator to decrease the amount of harmonic from harmonic current source $i_{l h}$ that effects on terminal voltage and source current.

\subsection{Harmonic voltage source}

Under constant harmonic voltage source $v_{s h}$ and $i_{l h}=0$, the terminal harmonic voltage $v_{t h}$ and the source harmonic current $i_{s h}$ are given as follows:

$$
\begin{aligned}
v_{t h} & =\frac{Y_{s}}{Y_{s}+Y_{c}+|G| K} v_{s h} \\
i_{s h} & =\frac{Y_{s}\left(Y_{c}+|G| K\right)}{Y_{s}+Y_{c}+|G| K} v_{s h}
\end{aligned}
$$

It's clear from the above two equations (15) and (16), that the harmonic suppression effect on the terminal voltage $v_{t h}$ and the source current $i_{s h}$ is decided by the control in the admittance IGlk because it is the only admittance available for change of control. Higher harmonic suppression effect is obtained by changing the constant $\mathrm{k}$ in direction that increase the denominator to decrease the amount of harmonic from harmonic voltage source $V_{s h}$ that effects on terminal voltage and source current.[Like the previous case.]

\subsection{Harmonic current and voltage source simultaneously}

Under constant harmonic current source $i_{l h}$ and harmonic voltage source $v_{s h}$, the terminal harmonic voltage $v_{t h}$ and the source harmonic current $i_{s h}$ are given as follows:

$$
\begin{aligned}
v_{t h} & =\frac{1}{Y_{s}+Y_{c}+|G| K} i_{l h}+\frac{Y_{s}}{Y_{s}+Y_{c}+|G| K} v_{s h} \\
i_{s h} & =-\frac{Y_{s}}{Y_{s}+Y_{c}+|G| K} i_{l h}+\frac{Y_{s}\left(Y_{c}+|G| K\right)}{Y_{s}+Y_{c}+|G| K} v_{s h}
\end{aligned}
$$

Journal of Engineering Sciences, Assiut University, Faculty of Engineering, Vol. 41, No. 2, March, 2013,E-mail address:jes@aun.edu.eg 
G. El-Saady et al, voltage and current harmonic suppression by shunt active filter feeding dc load on dc link, pp. 558 - 576

It's clear from the above two equations (17) and (18), that the harmonic suppression effect on the terminal voltage $v_{t h}$ and the source current $i_{s h}$ is decided by the control in the admittance IGlk because it is the only admittance available for changing of control.Higher harmonic suppression effect is obtained by changing the constant $\mathrm{k}$ in direction that increase the denominator in two terms of $i_{l h}$ and $v_{s h}$ to decrease the amount of harmonic from harmonic current source $i_{l h}$ and harmonic voltage source $V_{s h}$ that effects the terminal voltage and source current.[Like two previous cases.]

\section{Simulation results}

\subsection{System configuration in simulation model}

The system configuration as a simulation model is the same model system shown in FIGURE 1. The voltage source $v_{s}$ is three phase, 200V, and $60 \mathrm{~Hz}$. Table 1 shows the system parameters of the simulated model.

\section{Table 1}

System parameters of simulation model

\begin{tabular}{c|c}
\hline$R_{s}$ & $1.0 \Omega$ \\
\hline$L_{s}$ & $1.68 \mathrm{mH}$ \\
\hline$C$ & $92.1 \mu \mathrm{F}$ \\
\hline$L_{l}$ & $4.0 \mathrm{mH}$ \\
\hline
\end{tabular}

Figure. 2 shows the shunt active filter configuration for simulation model . We increase resistive load connected in parallel with $\mathrm{dc}$ link of active filter to $2 \mathrm{KW}$. The interconnection reactor $L_{a}$ is $8 \mathrm{mH}$ and the dc link capacitor $C_{d}$ is $500 \mu \mathrm{F}$, and the control strategy is explained before.

Three types of tests are carried out to prove the theoretical analysis mentioned above .Other tests to validate the control strategy under different conditions of distribution system are arranged. In the first test, a symmetrical three phase voltage source and a $2 \mathrm{~kW}$ harmonic-producing load consisting of a diode bridge circuit having a smoothing capacitor and a load resistor are used. In the second test, the harmonic producing load is omitted and a harmonic voltage source having $1.9 \%$ seventh harmonics is used. In the third test, a

Journal of Engineering Sciences, Assiut University, Faculty of Engineering, Vol. 41, No. 2, March, 2013,E-mail address:jes@aun.edu.eg 
G. El-Saady et al, voltage and current harmonic suppression by shunt active filter feeding dc load on dc link, pp. 558 - 576

harmonic voltage source having $1.9 \%$ seventh harmonics is used and the $2 \mathrm{~kW}$ harmonicproducing load are used simultaneously.

In all theoretical cases mentioned above the magnitude of $\mathrm{k}$ must increase in the negative direction for the denominators of the equations from (14) to (19) to increase because the line admittance $Y_{s}$ is equal to $(.714-j .452 \mathrm{~J})$ and the admittance of the capacitance $Y_{c}$ is equal to $(j 0.0347 \mathrm{~J})$ From the two quantities $Y_{s}$ and $Y_{c}$ the direction for increase the denominators via increase the constant $\mathrm{k}$ is in negative direction because the admittance IGlk is considered as imaginary part because the neutral of the active filter do not draw any active power from the distribution system. we don't need to know the real magnitude of $Y_{s}$ and $Y_{c}$ but only known the difference between them approximately to know in what direction to increase the magnitude of $\mathrm{k}$ positive or negative mentioned before .In most cases the negative direction is the correct direction because the inductance effect is always larger than the capacitance effect in distribution system.

\subsection{Test for hrmonic current source}

Figure. 5 shows the resulting waveforms $i_{s}$ and $v_{t}$ of the simulation test for the harmonic current source of a $2-\mathrm{kW}$ diode bridge circuit when suppressingn harmonic content of source current and terminal voltage. Table 2 shows the THDs of the terminal voltage, the source current and other quantities.

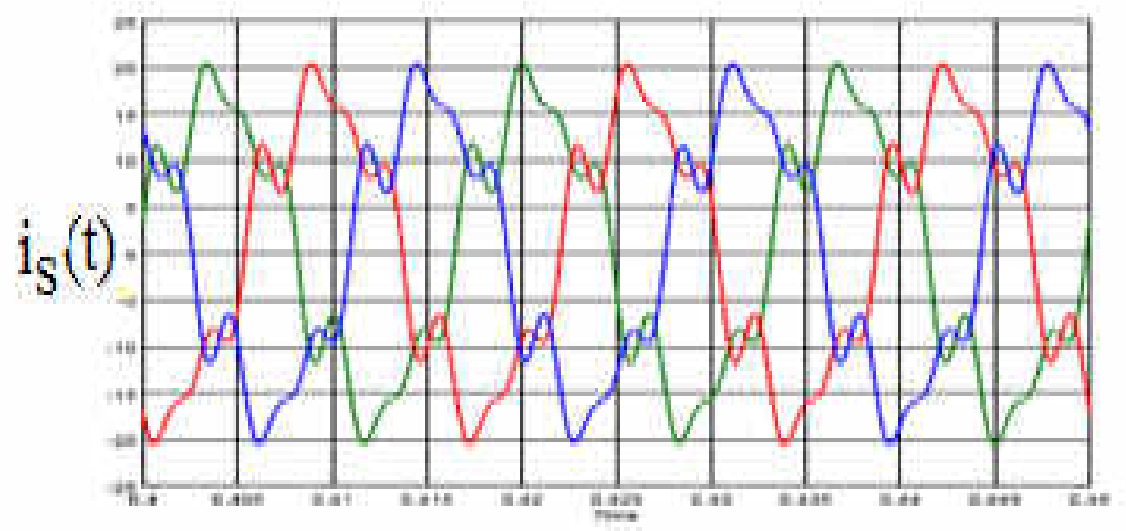

Journal of Engineering Sciences, Assiut University, Faculty of Engineering, Vol. 41, No. 2, March, 2013,E-mail address:jes@aun.edu.eg 
G. El-Saady et al, voltage and current harmonic suppression by shunt active filter feeding dc load on dc link, pp. 558 - 576

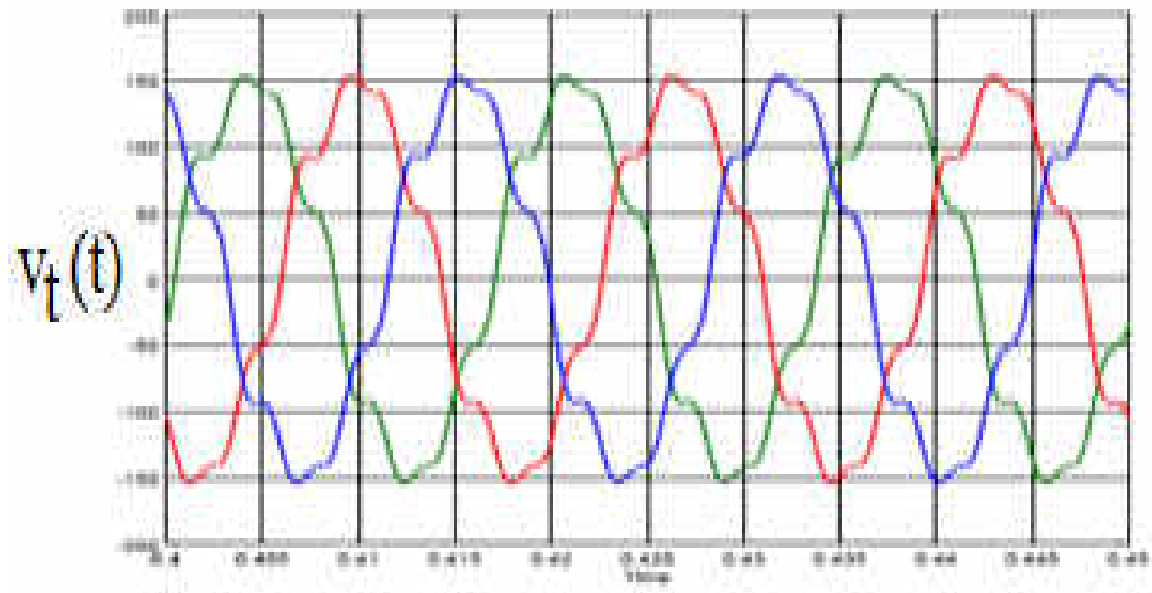

(b) For $\mathrm{k}=0$

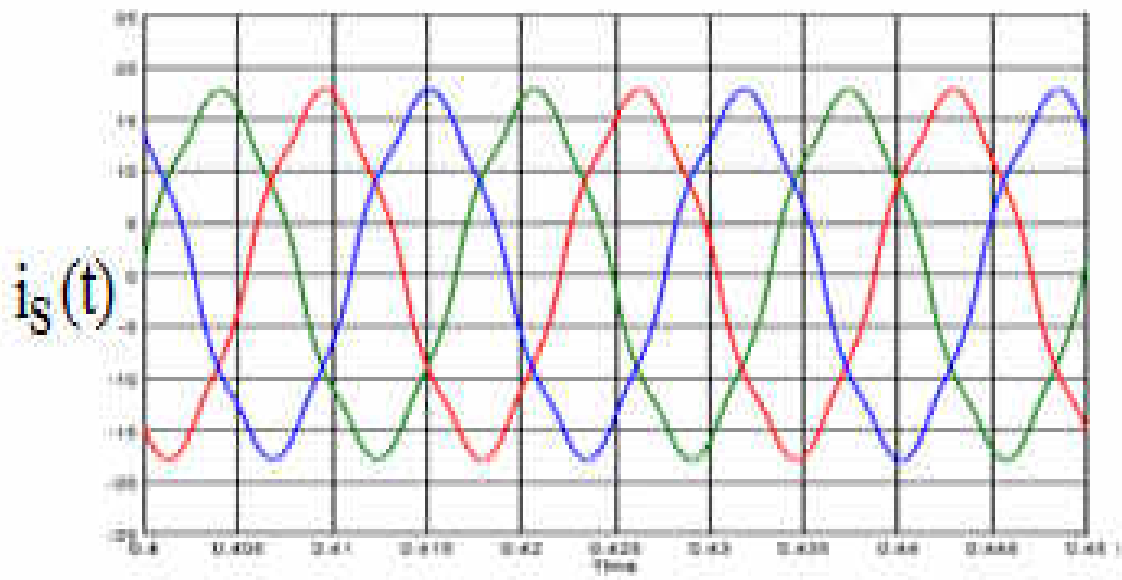

Journal of Engineering Sciences, Assiut University, Faculty of Engineering, Vol. 41, No. 2, March, 2013,E-mail address:jes@aun.edu.eg 
G. El-Saady et al, voltage and current harmonic suppression by shunt active filter feeding dc load on dc link, pp. 558 - 576

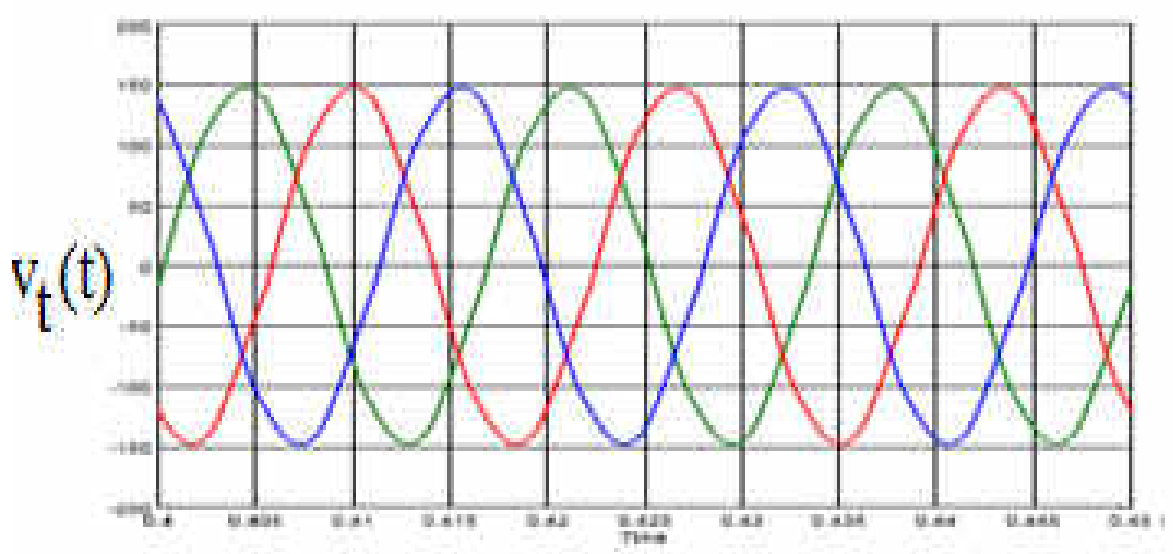

(b) For $\mathrm{k}=-10$

Fig. 5. Result waveforms for harmonic current source test

Table 2

Simulation results of harmonic current source

\begin{tabular}{|c|c|c|c|c|c|c|}
\hline \multirow{2}{*}{} & \multicolumn{6}{|c|}{ THD[\%] } \\
\cline { 2 - 7 } & not found & $K=0$ & $K=-1$ & $K=-2$ & $K=-3$ & $K=-10$ \\
\hline $\mathrm{i}_{\mathrm{c}}$ & - & 3.51 & 8.3 & 12.13 & 14.71 & 21.23 \\
\hline $\mathrm{vt}$ & 11.47 & 11.37 & 7.4 & 5.72 & 4.7 & 2.11 \\
\hline is & 50.39 & 24.95 & 17.36 & 13.81 & 11.5 & 5.2 \\
\hline $\mathrm{iL}$ & 21.26 & 21.4 & 22.1 & 23.04 & 23.76 & 25.54 \\
\hline
\end{tabular}

\subsection{Test for harmonic voltage source}

FIGURE 6 shows the resulting waveforms $i_{s}$ and $v_{t}$ of the simulation test of the harmonic voltage source having $1.9 \%$ seventh harmonics when suppressing harmonic content of source current and terminal voltage. Table 3 shows the THDs of the terminal voltage, the source current and other quantities.

Journal of Engineering Sciences, Assiut University, Faculty of Engineering, Vol. 41, No. 2, March, 2013,E-mail address: jes@aun.edu.eg 
G. El-Saady et al, voltage and current harmonic suppression by shunt active filter feeding dc load on dc link, pp. 558 - 576
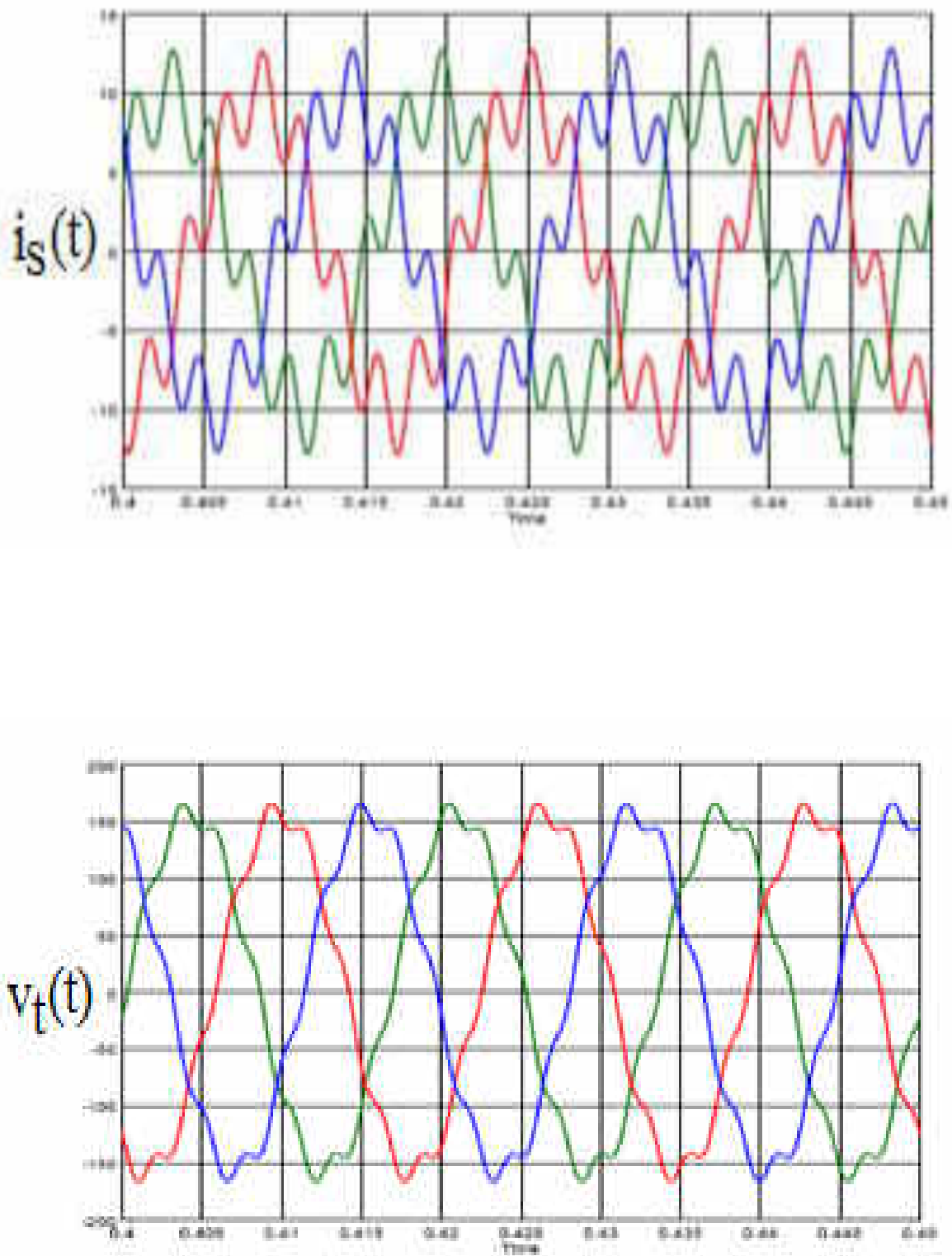

(b) For $\mathrm{k}=0$

Journal of Engineering Sciences, Assiut University, Faculty of Engineering, Vol. 41, No. 2, March, 2013,E-mail address:jes@aun.edu.eg 
G. El-Saady et al, voltage and current harmonic suppression by shunt active filter feeding dc load on dc link, pp. 558 - 576
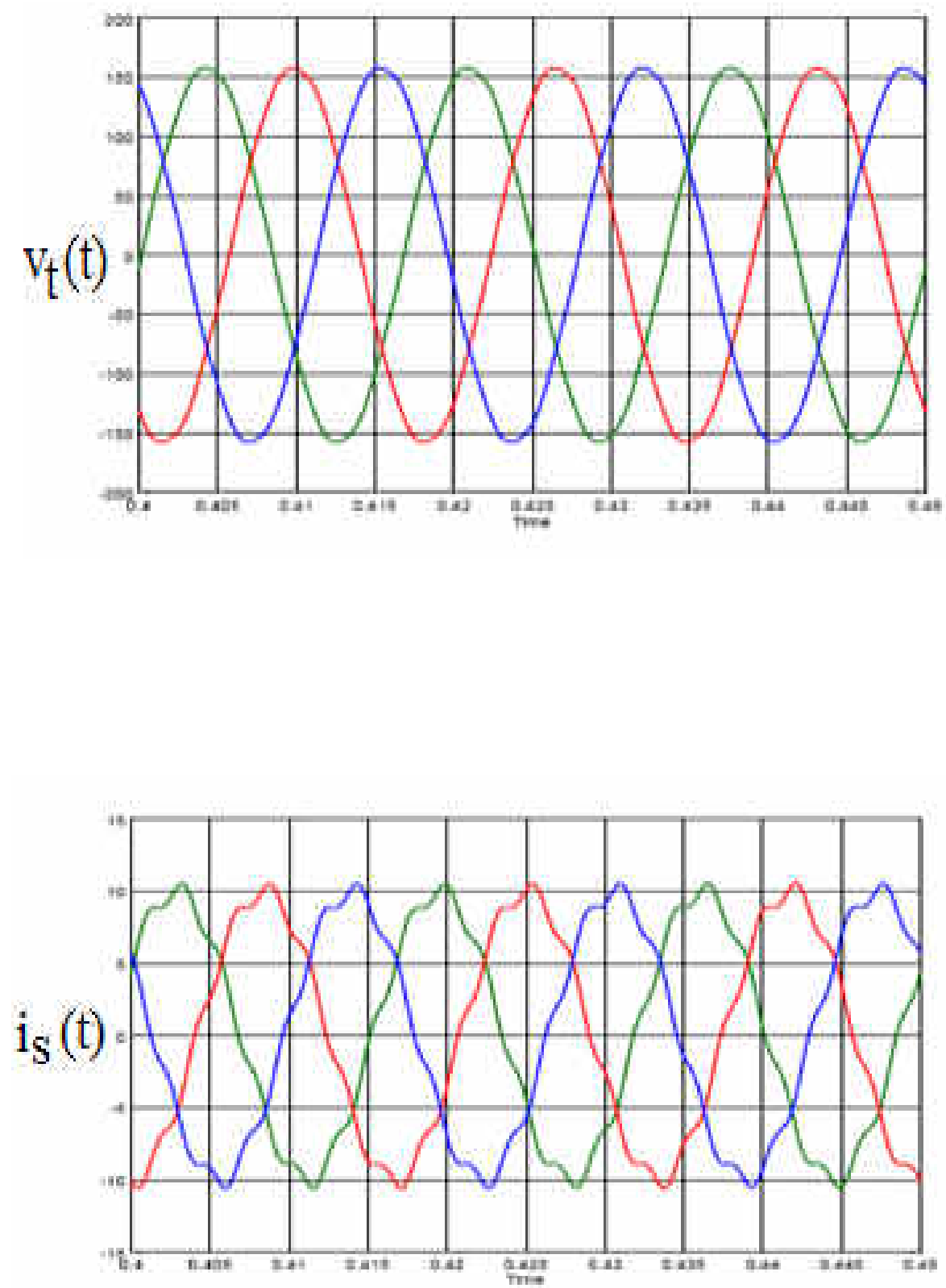

(b) For $\mathrm{k}=-10$

Fig. 6. Result wave forms for harmonic voltage source test

Journal of Engineering Sciences, Assiut University, Faculty of Engineering, Vol. 41, No. 2, March, 2013,E-mail address: jes@aun.edu.eg 
G. El-Saady et al, voltage and current harmonic suppression by shunt active filter feeding dc load on dc link, pp. 558 - 576

\section{Table 3}

Simulation results of harmonic voltage source

\begin{tabular}{|c|c|c|c|c|c|c|}
\hline & \multicolumn{4}{|c|}{ THOP\%] } & \multirow[b]{2}{*}{$k=3$} & \multirow[b]{2}{*}{$K=-10$} \\
\hline & not found & $K=0$ & $K=-1$ & $K=.2$ & & \\
\hline ic & $=m$ & 3.78 & 5.5 & 8.77 & 7.19 & 8.5 \\
\hline vit & 7.29 & 7.49 & 4.2 & 282 & 2.11 & 0.77 \\
\hline 18 & 51.02 & 28.59 & 16.33 & 11.62 & 9.6 & 6.84 \\
\hline v8 & 1.8 & 1.8 & 1.8 & 1.9 & 1.8 & 1.9 \\
\hline
\end{tabular}

\subsection{Test for Hharmonic current and voltage source simultaneously}

Figure 7 shows the resulting waveforms $i_{s}$ and $v_{t}$ of the simulation test of the harmonic voltage source having $1.9 \%$ seventh harmonics and harmonic current source of a $2-\mathrm{kW}$ diode bridge circuit simultaneously when suppressing harmonic content of source current and terminal voltage. Table 4 shows the THDs of the terminal voltage, the source current and other quantities.

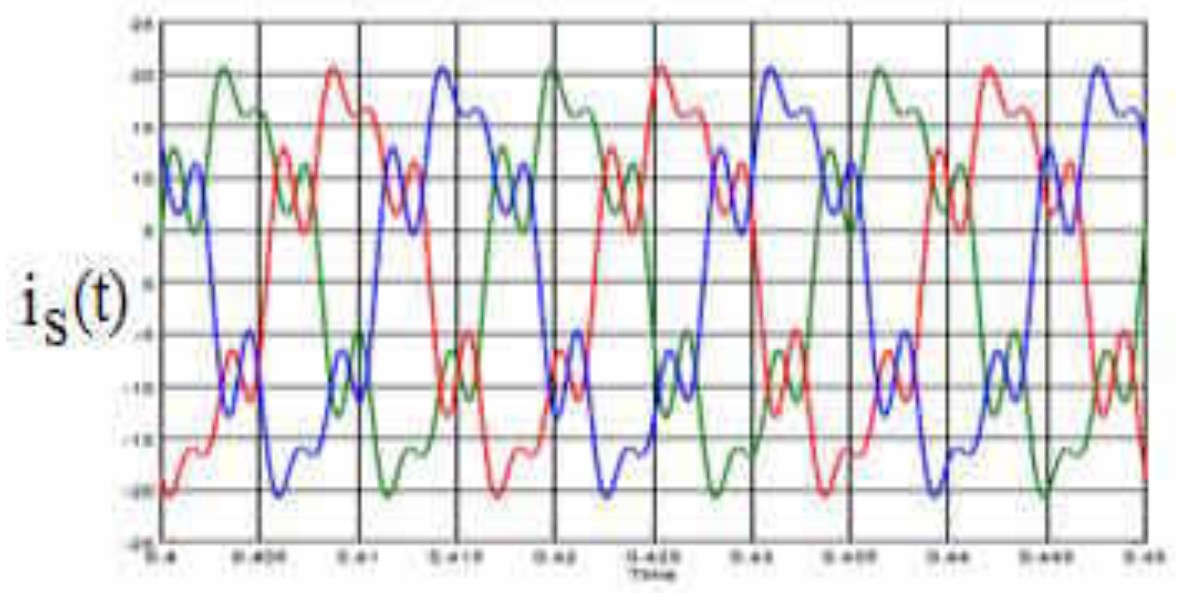

Journal of Engineering Sciences, Assiut University, Faculty of Engineering, Vol. 41, No. 2, March, 2013,E-mail address:jes@aun.edu.eg 
G. El-Saady et al, voltage and current harmonic suppression by shunt active filter feeding dc load on dc link, pp. $558-576$

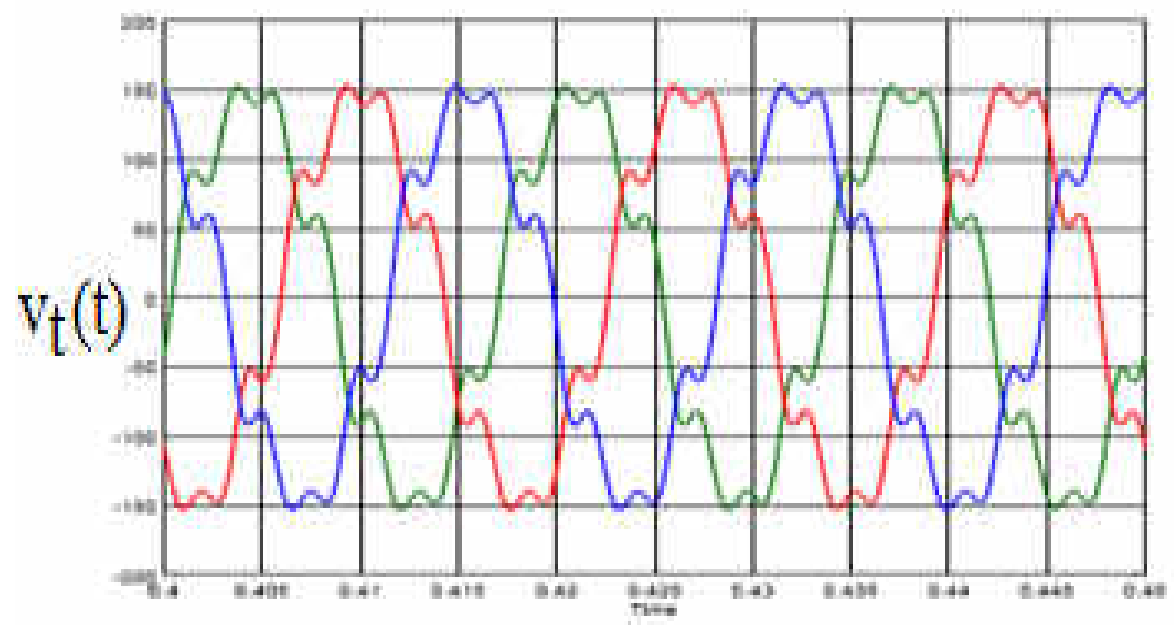

(b) For $\mathrm{k}=0$

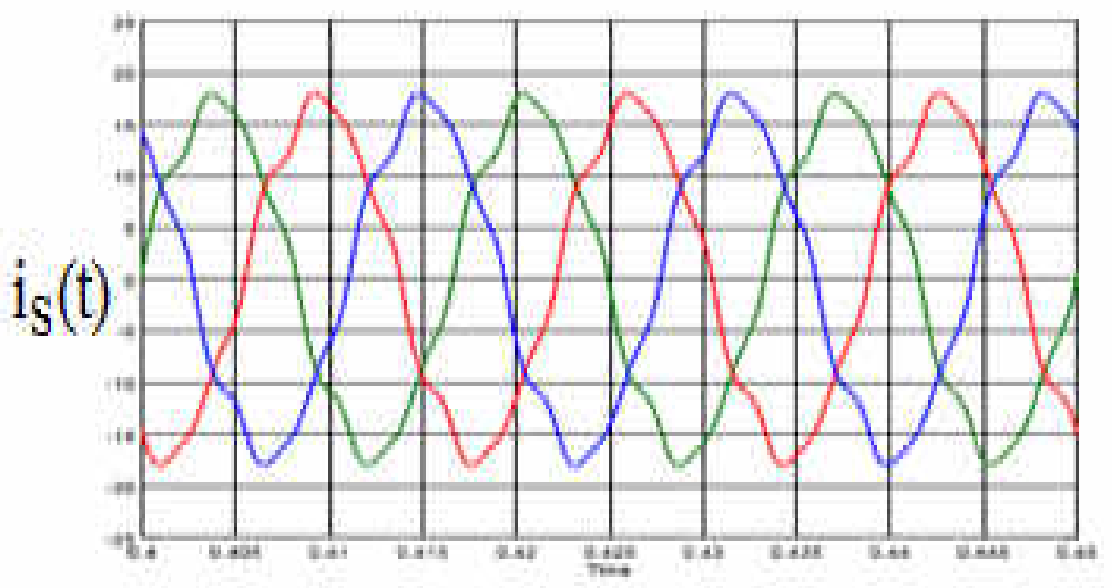

Journal of Engineering Sciences, Assiut University, Faculty of Engineering, Vol. 41, No. 2, March, 2013,E-mail address:jes@aun.edu.eg 
G. El-Saady et al, voltage and current harmonic suppression by shunt active filter feeding dc load on dc link, pp. 558 - 576

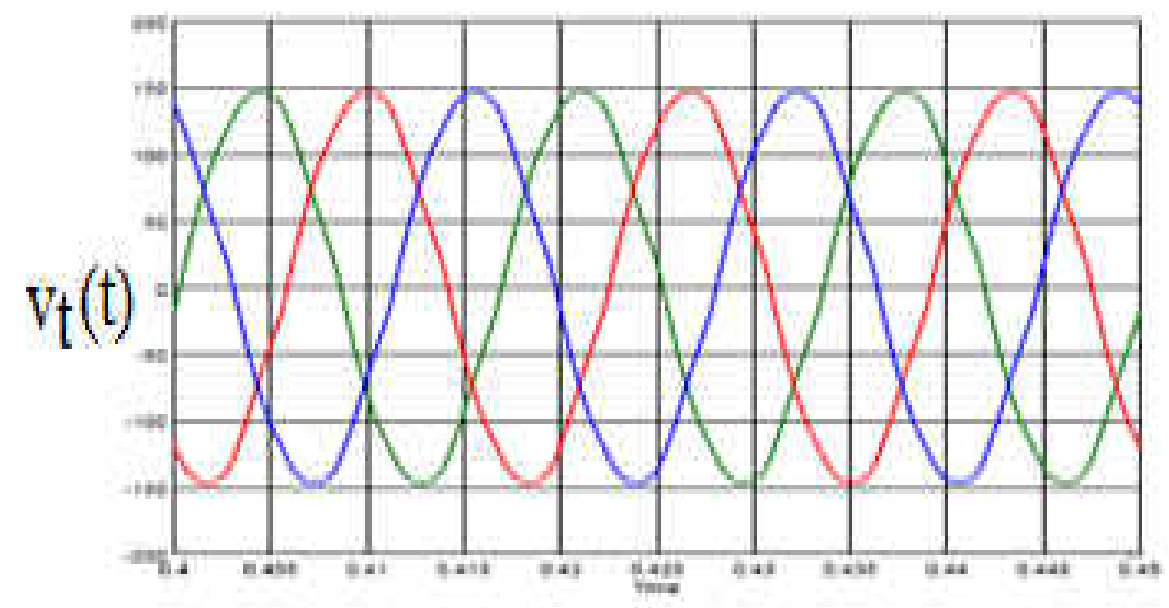

(f) For $\mathrm{k}=-10$

Fig. 7. Result waveforms for harmonic current and voltage source simultaneously test

\section{Table 4}

Simulation results of harmonic current and voltage source simultaneously

\begin{tabular}{|c|c|c|c|c|c|c|}
\hline & \multicolumn{4}{|c|}{ THO[Y] } & \multirow[b]{2}{*}{$\mathrm{K}=3$} & \multirow[b]{2}{*}{$k=10$} \\
\hline & not found & 00 & $\mathrm{~K}=\mathrm{n} \cdot 1$ & $R=-2$ & & \\
\hline ic & $\ldots$ & 353 & 10.45 & 1489 & 17,51 & 243 \\
\hline vt & 16.15 & 15.63 & 9.78 & 7.23 & 5.78 & 243 \\
\hline is & 65.35 & 32.3 & 22.1 & 17.15 & 14.12 & 6.99 \\
\hline il & 23.76 & 23.48 & 23.11 & 23.98 & 24.56 & 25.59 \\
\hline vs & 1.9 & 19 & 1.9 & 1.9 & 1.9 & 19 \\
\hline
\end{tabular}

\section{Conclusions}

This paper applies a specific control strategy for controlling the operation of shunt active filter for suppression of harmonics current source and terminal voltage. The results show that in the case of only harmonic current source representing harmonic-producing load, the THD of the terminal voltage reduces to the acceptable level but the source current needs some improvement to reach to the desired limit. Also, in the case of harmonic

Journal of Engineering Sciences, Assiut University, Faculty of Engineering, Vol. 41, No. 2, March, 2013,E-mail address: jes@aun.edu.eg 
G. El-Saady et al, voltage and current harmonic suppression by shunt active filter feeding dc load on dc link, pp. 558 - 576

voltage source representing the distorted source voltage, the THD of the terminal voltage is reduced to the acceptable level but the source current needs little improvement to reach the desired limit.

In the cases of harmonic current and voltage sources simultaneously. The THD of the terminal voltage have reduced to the acceptable level but the source current needs little improvement to reach the desired limit. In all above cases, k could not increase above (-10) because the increase of $\mathrm{k}$ has an effect on the period needed for system to reach to steady state.

\section{Acknowledgment}

The authors thank Eng. Mahmoud Abdallah Assistant Lecturer at Faculty of Engineering, Cairo University for his participations and helping .

\section{References}

[1] Fang Zheng Peng, Hirofumi Akagi, Akira Nabae, " A new approach to harmonic compensation in power systems." IEEE Trans. On Industry Electronics, Vol. 26, No. 6, Nov., 1990, pp. 983-990.

[2] Thomas M. Blooming, Daniel J. Carnovale, " Application of IEEE Std 519-1992 harmonic limits." IEEE Conference Publications, Jun., 2006, pp. 1-9.

[3] Bhim Singh, Kamal Al-Haddad, Ambrish Chandra, " A review of active filters for power quality improvement." IEEE Trans. On Industrial Electronics, Vol. 46, No. 5, Oct., 1999, pp. 960-971.

[4] M.El-Habrouk, M.K.Darwish, P.Mehta, " Active power filters: a review." IEEE Proc.Electr. Power Appl., Vol. 147, No. 5, Sep., 2000, pp. 403-413.

[5] Zainal Salam, Tan Perng Cheng, Awang Jusoh, "Harmonics mitigation using active power filter: a technological review.” Elektrika Journal, Vol. 8, No. 2, 2006, pp. 17-26.

[6] Jinjun. Liu, Yihong He, Honggyu Li, Fang Zhuo, Zhaoan Wang, " Quantitative analysis of shunt active filter compensation characteristics under different rectifier load situations." IEEE Trans. On Industry Electronics, Vol. 4, 2002, pp. 1241-1246.

[7] Hirofumi Akagi, Sunt Srianthumrong, Yasuhiro Tamai, "Comparisons in Circuit Configuration and Filtering Performance between Hybrid and Pure Shunt Active Filters." IEEE Trans. On Industrial Applications, Vol. 2, Oct., 2003, pp. 1195-1202.

[8] Zhong. Chen, Dehong. Xu, “ Design and implementation of a DSP-based shunt active power filter in three-phase four-wire system." IEEE Conference Publications, Vol. 1, Nov., 2003, pp. 542-547.

[9] Chung-chuan Hou, Yung-fu Huang, " Design of single-phase shunt active filter for threephase four-wire distribution systems." IEEE Conference Publications, Sep., 2010, pp. 1525-1528.

[10] Nassar Mendalek, Kamal Al-haddad, “ Modeling and nonlinear control of shunt active power filter in the synchronous reference frame." IEEE Conference Publications, Vol. 1, 2000, pp. 30-35.

[11] Pichai Jintakosonwit, Hirofumi Akagi, Hideaki Fujita, Satoshi Ogasawara, "Implementation and performance of automatic gain adjustment in a shunt active filter for

Journal of Engineering Sciences, Assiut University, Faculty of Engineering, Vol. 41, No. 2, March, 2013,E-mail address:jes@aun.edu.eg 
G. El-Saady et al, voltage and current harmonic suppression by shunt active filter feeding dc load on dc link, pp. 558 - 576

harmonic damping throughout a power distribution system.” IEEE Trans. On Power Electronics, Vol. 17, No. 3, May., 2002, pp. 438-447.

[12] Pichai Jintakosonwit, Hideaki Fujita, Hirofumi Akagi, "Control and performance of a fully-digital-controlled shunt active filter for installation on a power distribution system." IEEE Trans. On Power Electronics, Vol. 17, No. 1, Jun., 2002, pp. 132-140.

[13] Mauricio Aredes, Luis F. C. Monteiro, “ A control strategy for shunt active filter." IEEE Conference Publications, Vol. 2, Oct., 2002, pp. 472-477.

[14] Takaharu Takeshita, Nobuyuki Matsui, " Control of active filters using source current detection." IEEE Industrial Electronics Society Conference, Vol. 2, Nov., 2003, pp. 15151520.

[15] L. H. Tey, P. L. So, Y. C. Chu, “Improvement of power quality using adaptive shunt active filter.” IEEE Trans. On Power Delivery, Vol. 20, No. 2, Apr., 2005, pp. 1558-1568.

[16] Hideaki Fujita, Hirofumi Akagi, “Voltage regulation performance of a shunt active filter intended for installation on a power distribution system.” IEEE Conference Publications, Jun., 2005, pp. 2578-2584.

[17] Filipe Ferreira, Luis Monteiro, Joao L. Afonso, Carlos Couto, “ A control strategy for a three-phase four-wire shunt active filter." IEEE Conference Publications, Nov., 2008, pp. 411-416.

[18] Parithimar Kalaignan, Sree Renga Raja, “ Harmonic elimination by shunt active filter using PI controller.” IEEE Conference Publications, Dec., 2010, pp. 1-5.

[19] Musa Yusup Lada, Othman Mohindo, Aziah Khamis, Jurifa Mat Lazi, Irma Wani Jamaludin, "Simulation single phase shunt active filter based on p-q technique using matlab/simulink development tools environment." IEEE Conference Publications, Apr., 2011, pp. 159-164.

[20] Jeeva S. Pridaaa, P Tamizharasi, J. Baskaran, “ Implementation of synchronous reference frame strategy based shunt active filter." IEEE Conference Publications, Vol. 2, Apr., 2011, pp. 240-244.

[21] Takaharu Takeshita, Takahiro Masuda, Nobuyuki Matsui, " Current waveform control of distributed generation system for harmonic voltage suppression." IEEE Power Electronics Specialists Conference, Vol. 2, Aug., 2001, pp. 516-521.

[22] Takaharu Takeshita, Nobuyuki Matsui, " Current waveform control of distributed generation system for harmonic suppression on distribution system." IEEE Industrial Electronics Society Conference, Vol. 1, Nov., 2002, pp. 532-537.

[23] Takaharu Takeshita, Nobuyuki Matsui, " Current waveform control of PWM converter system for harmonic suppression on distribution system." IEEE Trans. On Industry Electronics, Vol. 50, No. 6, Dec., 2003, pp. 1134-1139.

Journal of Engineering Sciences, Assiut University, Faculty of Engineering, Vol. 41, No. 2, March, 2013,E-mail address:jes@aun.edu.eg 
G. El-Saady et al, voltage and current harmonic suppression by shunt active filter feeding dc load on dc link, pp. 558 - 576

\section{ملخص :}

يقدم البحث استر اتيجية تحكم لنظيم عمل المرشح الفعال التوازى وذللك لاخماد وتقليل التو افقيات فى التيار

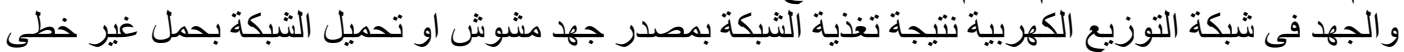

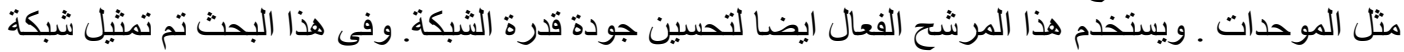

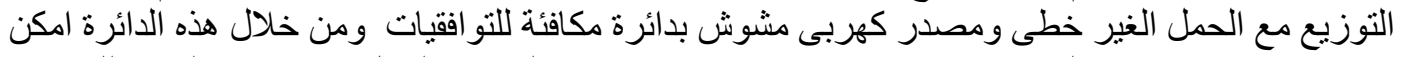

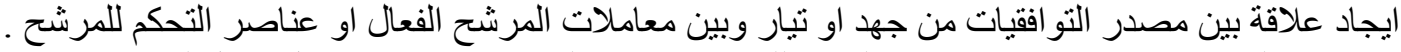

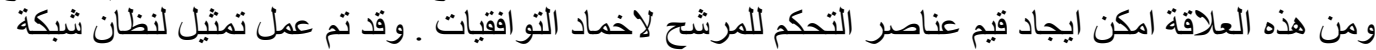

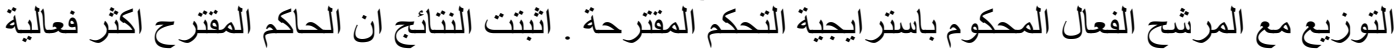

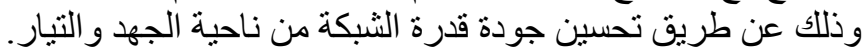
الكلمات المفتاحبة :

1- المرشح الفعال 2- جودة القدرة 3- اخماد التوافقيات فى شبكة التوزيع المعامل الكلى لتشويش التو افقيات 